\title{
A COLERIDGEAN AGAINST THE MEDICAL CORPORATIONS: JOHN SIMON AND THE PARLIAMENTARY CAMPAIGN FOR THE REFORM OF THE MEDICAL PROFESSION 1854-8
}

by

\section{T. N. STOKES *}

On 23 March 1858 W. F. Cowper, in his capacity as President of the General Board of Health, introduced into the House of Commons his 'Bill to regulate the qualification of Practitioners in Medicine and Surgery'. This Bill was subsequently to become the 1858 Medical Act. Its author was John Simon, then Medical Officer to the Board, whose office memorandum has survived to prove conclusively that his was indeed the hand behind Cowper's Bill. ${ }^{2}$ It is Simon's role in the Victorian "medical reform" movement ${ }^{3}$ which forms the subject of the first half of this paper, for his involvement raises two important questions: first, what exactly did Simon himself want as far as medical reform was concerned; secondly, how did his plans here relate to his views on the purpose of the Board of Health in particular, and of the role of central government in general. I shall argue that John Simon sought to implement Coleridgean ideas on medical reform which had been transmitted to him by J. H. Green, ideas aiming for the creation of "state medicine". But this is not the whole story, for Simon and Cowper's Medical Reform Bill was amended in its passage through Parliament, with the result that the 1858 Medical Act differed from the initial Bill in a number of important respects. The second half of this paper is devoted to the parliamentary campaign for the reform of the medical profession over the years 1854-8. To this end it will be necessary to consider the differing positions towards medical reform of the two medical corporations whose élite had access to political power and thus to government

\section{*T. N. Stokes, BA, M.Phil., c/o 39 Alder Grove, Lytham St Annes, Lancs. FY8 4LA.}

\footnotetext{
${ }^{1}$ This paper is a shortened version of my unpublished Cambridge University M.Phil. thesis: T. N. Stokes, 'The campaign for the reform of the medical profession in mid-Victorian England' (1987). The support and encouragement of my supervisor, Dr Perry Williams of the Wellcome Unit for the History of Medicine at Cambridge, is gratefully acknowledged. I should also like to thank Drs Irvine Loudon and W. F. Bynum for their comments on how the thesis could best be turned into a paper. The work was supported by a British Academy studentship.

2 John Simon, English sanitary institutions, reviewed in their course of development, and in some of their political and social relations, 2nd ed., London, John Murray, 1897, p. 272; Charles Newman, The evolution of medical education in the nineteenth century, London, Oxford University Press, 1957, pp. 184-5.

${ }^{3}$ For two recent studies in this area see: Irvine Loudon, Medical care and the general practitioner 1750-1850, Oxford, Clarendon Press, 1986; and Ivan Waddington, The medical profession in the Industrial Revolution, Dublin, Gill and Macmillan, 1984. But Margaret Pelling's comment in her historiographical review article 'Medicine since 1500' still holds true: "it is notable that no satisfactory secondary account of the nineteenth-century 'medical reform' movement has yet been produced". P. Corsi and P. Weindling (eds.), Information sources in the history of science and medicine, London, Butterworths, 1983, p. 387.
} 


\section{T. N. Stokes}

legislation: the Royal College of Physicians of London, and the Royal College of Surgeons of England. It will be argued that the 1858 Medical Act represented a balance of power between Simon and the two Royal Colleges, and that the events of 1856-8 were about whether the State or the medical corporations should have control of the medical profession.

\section{I}

John Simon has been well served by Royston Lambert's biography. ${ }^{4}$ But Lambert's book sheds surprisingly little light on why Simon held the views on medical reform which he so assiduously pressed Parliament, through Cowper, to accept. To understand why Lambert was unable to answer this question satisfactorily, one must discuss his approach to Simon, which sets him firmly on one side of the historiographical fence which has divided historians seeking to explain the growth of central government and state intervention, two characteristic features of the Victorian period. Lambert, when he began his biography, believed that Simon's acts in central government would prove to be an example of Oliver MacDonagh's "self-generating bureaucratic growth". MacDonagh $^{6}$ had previously argued that the nineteenthcentury "revolution" in government was not so much the product of an external ideology (i.e., Benthamism) as the result of a teleological process within the administration itself. In such a scheme, government administrators (in this case Simon) are reduced to mere pragmatists-men who simply try to solve "intolerable" social problems as they arise. On completing his study, however, Lambert doubted whether Simon really exemplified MacDonagh's thesis. ${ }^{7}$ One way out of this impasse would be to claim that Simon, like his great rival, Edwin Chadwick, was motivated by an ideology (in Chadwick's case, Benthamism). But Lambert's adherence to MacDonagh's thesis counters any attempt to elucidate and define Simon's ideology. Whilst Lambert correctly pointed out that "Benthamism, which inspired the practical action of so many of his generation, could not in its crude hedonism and social atomism have been wholly congenial to one whose interests in German idealist philosophy was notorious", 8 he did not explore the possibility that Simon had an ideological alternative to Benthamism. On the contrary, he claimed that Simon "contributed powerfully to establish the tradition of gradual, empirical reform on the basis of irrefutable social research which reached its culmination later in the century in

\footnotetext{
${ }^{4}$ Royston Lambert, Sir John Simon 1816-1904 and English social administration, London, MacGibbon \& Kee, 1963.

${ }^{5}$ In an earlier paper, Lambert had argued that the implementation of state vaccination, with which Simon was closely associated, "exhibited those 'spontaneous developments in administration' which Dr MacDonagh has recently brought to our attention": 'A Victorian National Health Service: state vaccination 1855-71', Hist. J., 1962, 5: 1-18, p. 17.

6 'The nineteenth-century revolution in government: a reappraisal', ibid., 1958, 1: 52-67.

7 "Simon's large personality, his a priori notions and ambitions, his idiosyncrasies make the development of the Medical Department only a partial exemplification of the trend of government growth so excellently analysed by Dr MacDonagh . . . Though the inherent momentum of administration played a large part in the expansion of the Medical Department, its 'natural' tendency was sometimes impeded or diverted by Simon's influence"; Lambert, op. cit., note 4 above, p. 460n. S. J. Novak, 'Professionalism and bureaucracy: English doctors and the Victorian public health administration', J. soc. Hist., 1973, 4: 440-62, pp. 449-50.

${ }^{8}$ Lambert, op. cit., note 4 above, p. 33.
} 


\section{John Simon and the reform of the medical profession}

Fabianism." Pace Lambert, I shall argue that Simon, like Chadwick, did have an ideology which accounts for both his position on medical reform, and his views concerning the role of medicine in Victorian Government. This ideology had its origins, not in Bentham, but in the other of the "two great seminal minds of England in their age", ${ }^{10}$ Samuel Taylor Coleridge, via the writings of Simon's mentor J. H. Green. Such a claim - that Simon as a civil servant was striving to attain Green's desire for a Coleridgean State in which medicine would occupy pride of place-is, to my knowledge, novel. For while the influence of Coleridge on nineteenth-century thought is not doubted by scholars, he was thought until recently to have had no positive influence on the development of Victorian government. ${ }^{11}$ There would appear to be two reasons for this. First, historians have all too often sided with J. S. Mill's unflattering remarks on the Coleridgeans in his Autobiography, where he categorized them as being merely aspects of the "reaction of the nineteenth century against the eighteenth". ${ }^{2}$ Secondly, there exists as yet no detailed study of the dissemination of Coleridge's ideas in the 1830 s and 40 s - notably, to a generation of doctors and lawyers at King's College, London, where Green held the Chair of Surgery and another Coleridgean, J. J. Park, that of Law and Jurisprudence. ${ }^{13}$ This view of Simon as a Coleridgean, however, receives further support when it is noted that he counted among his intimate friends in Paris several Saint-Simonians; ${ }^{14}$ and that he was also a close friend of Ruskin ${ }^{15}$ and acquainted with the latter's Christian Socialist circle, in particular with Charles Kingsley and W. F. Cowper. ${ }^{16}$ Such men, if not all

\footnotetext{
9 Ibid., p. 614.

10 J.S. Mill, Dissertations and discussions (1867), quoted in B. Willey, Nineteenth century studies, London, Harmondsworth, 1964, p. 1.

11 The exception is Peter Gowan's 'The origins of the administrative elite', New Left Rev., 1987, 162:4-34. I am grateful to an anonymous referee for this reference. David Calleo, Coleridge and the idea of the modern state, New Haven, Yale University Press, 1966 is an exercise in political theory. Ben Knights, The idea of the clerisy in the 19th century, Cambridge University Press, 1978, traces Coleridge's literary influence.

12 J.S. Mill, Autobiography, in the Collected works of John Stuart Mill, J. M. Robson and J. Stillinger (eds.), vol. 1, London, Routledge and Kegan Paul, 1981, p. 169; for an excellent discussion of this point, with a reappraisal in favour of the Coleridgeans, see William Thomas's The philosophic radicals, Oxford, Clarendon Press, 1979, pp. 168-205.
}

${ }^{13}$ S. T. Coleridge, On the constitution of the Church and State, ed. John Colmer, London, Routledge and Kegan Paul, 1976, introduction, p. Ixi.

${ }^{4}$ Simon was, through his father, an intimate friend of Charles Duveyrier, and at the latter's house in Paris met such other notable Saint-Simonians as Père Enfantin, Arlès-Dufour, and the Chevaliers. He seems to have made Duveyrier's acquaintance in his student days (late 1830s and early 1840s), by which time the Saint-Simonians had become respectable members of Parisian society-they were no longer a political movement but "a spirit and a circle of friends interested in the application of certain Saint-Simonian ideas, particularly in the organization of industry". See John Simon, Personal recollections, London, privately printed, 1897, pp. 6-7; G. G. Iggers, The cult of authority: the political philosophy of the Saint-Simonians, The Hague, M. Nijhoff, 1958, pp. 36-7.

${ }_{15}$ We have it on the authority of Ruskin's father that he believed Simon to be one of the three men (the other two being Arthur Helps and Thomas Carlyle) behind his son's shift away from aesthetic to political criticism in the late $1850 \mathrm{~s}$, a shift exemplified by John Ruskin's essays of 1858 and 1860 attacking the prevalent "Manchester" (i.e., laissez-faire) school of thought. See Tim Hilton, John Ruskin. The early years, 1819-1859, New Haven, Yale University Press, 1985, pp. 246-7; Lambert, op. cit., note 4 above, p. 489.

${ }^{16}$ Ibid., pp. 487-90, 589-91 (Ruskin); pp. 199, 207 (Kingsley); p. 33 (Cowper). Both Cowper and Simon had frequent correspondence with Ruskin. See John Ruskin, Collected works, ed. E. T. Cook and Alexander Wedderburn, vols. 36 and 37 (letters), London, George Allen, 1909. 


\section{T. N. Stokes}

"Coleridgeans" (the Saint-Simonians obviously were not), shared with Coleridge a dislike of democracy, Benthamite individualism, and laissez-faire. Another possible influence on Simon which Lambert does not discuss is the German concept of "medical police" which, as George Rosen ${ }^{17}$ and Roy MacLeod ${ }^{18}$ have shown, first found favour in Scottish academic circles in the first few decades of the nineteenth century and was later applied to matters of public health by a number of sanitary reformers - notably by the Gloucestershire medical practitioner Henry Rumsey. ${ }^{19}$ As we shall see, Simon indeed used the term "medical police" and he was certainly aware of Rumsey's writings. But it would appear that the two men moved in different $\operatorname{circles}^{20}$ and that each had his own separate programme for the creation of "State Medicine". 21

\section{II}

By those who heard it, this address is likely to be still remembered as a wonderful oratorical display. It seemed one continuous flow of lofty argumentative eloquence, and the delivery of it was singularly earnest and effective. To the youths who then first heard Mr. Green, it was as the opening of a new world. The writer of the present Memoir was among them. ${ }^{22}$

John Simon was seventeen when he heard J. H. Green deliver this address in King's College, London at the commencement of the autumn medical session of $1832 .{ }^{23} \mathrm{He}$ was, as he put it, then a "very unformed lad, looking forward to become in another year one of Mr. Green's surgical apprentices". ${ }^{24}$ It marked the start of Simon's acquaintance with Green, which very soon matured into a friendship of life-long intimacy, the younger man regarding the elder with filial devotion. ${ }^{25}$ On Green's death in 1863 Simon edited and prepared for publication, together with a memoir of his life, Green's thirty years' attempt at "systematizing, developing, and establishing the doctrines of the Coleridgean philosophy": his Spiritual philosophy of $1865 .{ }^{26}$ For

${ }^{17}$ G. Rosen, 'What is social medicine?', Bull. Hist. Med., 1947, 21: 675-734; idem, 'Cameralism and the concept of medical police', ibid., 1953, 27: 21-42; idem, 'The fate of the concept of medical police', Centaurus, 1957, 5: 97-113.

${ }^{18}$ R. M. MacLeod, 'The anatomy of state medicine: concept and application', in F. N. L. Poynter (ed.), Medicine and science in the 1860s, London, Wellcome Institute for the History of Medicine, 1968; idem, 'The frustration of state medicine, 1880-1899', Med. Hist., 1967, 11: 15-40.

${ }^{19} \mathrm{He}$ published widely on such topics as medical relief, vital statistics and sanitary legislation. Of particular relevance here are: H. W. Rumsey, Essays on state medicine, London, John Churchill, 1856; and idem, 'Remarks on state medicine in Great Britain', Br. Med. J., 1867, ii: 197-204.

${ }^{20}$ Lambert, op. cit., note 4 above.

21 As MacLeod notes: “His [Simon's] was not the eighteenth century's scheme of medical police, nor Chadwick's scheme of sanitary police, nor was it Rumsey's scheme with its legal connotations" ('Anatomy', op. cit., note 18 above, p. 208). While the exact nature of Rumsey's programme remains to be elucidated, it is clear that he was indebted to such German authors as Frank and Niemann. In his Essays on state medicine, for example, the reader is referred to "J. P. Frank's classical work on Medicinische Polizei" (Essays, op. cit., note 19 above, p. 3). On Frank see Rosen, 1957, op. cit., note 17 above.

22 J. H. Green, Spiritual philosophy, ed. John Simon, 2 vols., London, Macmillan and Co., 1865, vol. 1, pp. $\mathbf{x i x}-\mathbf{x x}$.

${ }^{23}$ J. H. Green, An address delivered at King's College, London, at the commencement of the medical session, October 1st, 1832, London, B. Fellowes, 1832.

24 Idem, op. cit., note 22 above, p. xx.

25 "I write as with the affection of a son", ibid., p. xlviii.

26 Ibid., pp. xxxiv-v. 


\section{John Simon and the reform of the medical profession}

Green himself had been a disciple of Coleridge since $1816^{27}$ and on the latter's death in 1834 became his literary executor-one of his duties being the publication of a system of the Coleridgean philosophy. Simon, through Green, was also to espouse Coleridgean ideas, for he saw himself as following in his former apprentice-master's footsteps. Simon, who had nothing but praise for Green's writings, be they on medical reform ${ }^{28}$ or physiology, ${ }^{29}$ was also to become Surgeon to St Thomas's Hospital and had discussed idealist philosophy in Germany (on Green's recommendation) with Schelling and Tieck. ${ }^{30}$ His career also echoed that of Green. Until 1848 Simon had been a surgeon of the "conservative" school, teaching medical students at St Thomas's a system of pathology which had its roots in Green's German-inspired anti-materialist definition of life. After 1848, and especially with his entry into central government service as Medical Officer to the General Board of Health in 1855, Simon proceeded to put Green's ideas on medical reform into practice.

During the first half of his career, Simon emphasized pathology as the scientific basis of medical practice. This interest did not disappear after Simon entered public service, but found expression in his writings on sanitary reform. For his labours in pathology Simon was elected a Fellow of the Royal Society. He was indebted to Green for his views on the nature of life, which he alluded to in his $1847 \mathrm{St}$ Thomas's lectures On the aims and philosophic method of pathological research. "Life", Simon maintained with Green, ${ }^{31}$ was an idea "supra-causal and absolute". ${ }^{32}$ Thus both his and Green's position echoed, not surprisingly, that of Coleridge and John Abernethy in their dispute over the nature of life with William Lawrence. ${ }^{33}$

It was not until the second half of his career that Simon was able to implement any measures concerning medical reform, but their foundation was laid by Green's King's College address of 1832. This address was "in great part founded on the views concerning the Clerisy or National Church which Coleridge had then recently advanced in his work on the Constitution of Church and State". ${ }^{34}$ Green did not simply parrot his friend's ideas. Coleridge was chiefly concerned with showingagainst the "Liberalists and Utilitarians"- that a "permanent, nationalized, learned order, a national clerisy or church, is an essential element of a rightly constituted nation" 35 and gave little thought to the role of the professions in relation to the clerisy. Green on the other hand believed that the clerisy or "learned class" was synonymous with the professions. Moreover, he held the view that each of the "three great

${ }^{27}$ Ibid., pp. viii-ix.

28 "I cannot refrain, however, from making especial reference to the works of my honoured friend, Mr. Green; who has illustrated all topics of Medical polity with consummate judgement and mastery": J. Simon, Observations regarding medical education, London, Henry Renshaw, 1842, p. 33.

29 "[M]y own deep obligations to his great intellect" (on Green's Hunterian Oration of 1840, Vital dynamics, London, William Pickering, 1840): J. Simon, On the aims and philosophic method of pathological research, London, Henry Renshaw, H. Bailliere, 1847, p. 34n.

${ }^{30}$ Lambert, op. cit., note 4 above, p. 24.

${ }^{31}$ Green, op. cit., note 29 above.

${ }^{32}$ Simon, op. cit., note 29 above, p. 34.

${ }^{33}$ This dispute occurred in 1816. For an account see: O. Temkin, 'Basic science, medicine, and the Romantic era', Bull. Hist. Med., 1963, 37: 97-129; T. H. Levere, Poetry realized in nature: S. T. Coleridge and early nineteenth-century science, Cambridge University Press, 1981, pp. 45-52.

${ }^{34}$ Green, op. cit., note 22 above, pp. xviii-xix.

${ }^{35}$ Coleridge, op. cit., note 13 above, p. 69. 


\section{T. N. Stokes}

professions" ("the Legal, Ecclesiastical and Medical") predominated in one of the three periods or "epochs" of history. Law and its attendant science, jurisprudence, flourished first; the "Ecclesiastical Profession" and its attendant science, theology, second; and now, finally, medicine, with its attendant science, physiology, was to reign triumphant. ${ }^{36}$ For the third epoch can

only have for its object the relations both of the citizen and of the individual man, to nature and to the complex organ of his dependence on, intercommunion with, and control over, nature. The science, of course, must be Physiology, and the profession, or learned class, by whom that science is ... to be applied to the needs of the community, the medical. ${ }^{37}$

Seen from this vantage point, that one had now reached the historical epoch in which the medical profession was to be the head of the "learned class", Green's writings on medical reform ${ }^{38}$ become comprehensible, as a means towards this end. They may be summarized thus:

First, a learned class should be formed which had as its common object the cultivation of physiology (which encompassed pathology) and the application of this, by the medical profession, "to the 'needs and commodities' of social man". 39

Second, there should exist suitable institutions and teachers to achieve the first object.

Third, there should be established a "governing body, council or college, for regulating the affairs and protecting the professional interests; and emanating from and responsible to the Government of the country for the efficiency of the Profession, and for the performance of its duties private, as well as national". ${ }^{40}$ This governing council was to "select and appoint its members", for only such an arrangement would ensure that it contained a "sufficient number of men most distinguished in the Profession for their talents and attainments". 41 The council was itself to have four distinct functions: first, the "superintendence of the Education of the Profession, and the regulation of all institutions, colleges, \&c., for that purpose" (i.e., to achieve the first two objects); second, to regulate the "practical departments" of the medical profession so as to safeguard the public from irregular practice and to "provide for the public criteria of competence, skill, and integrity"; third, to promote medicine both as a science and as a subject suitable for a gentleman; fourth, "as an administrative department of the Government of the country, [to regulate] all matters relating to public health".

${ }^{36}$ Green, op. cit., note 23 above, pp. 2-3, 4-14.

37 Ibid., p. 14.

38 J. H. Green, Distinction without separation: a letter to the President of the College of Surgeons, London, Hurst, Chance, \& Co., 1831; idem, Suggestions respecting the intended plan of medical reform, London, S. Highley, 1834; idem, The touchstone of medical reform, London, S. Highley, 1841.

${ }^{39}$ Idem, Suggestions, op. cit., note 38 above, pp. 2-3.

40 Ibid., p. 4.

41 Ibid., p. 32. 


\section{John Simon and the reform of the medical profession}

These three objects, Green believed, had to be achieved in order to facilitate-by providing one uniform medical learned class - the desired reunion of the professions of Law, Medicine and the Church as one "national learned class":42

And if, as cannot be doubted, it be the duty of a Government to provide for the well-being of social man in his relations and duties as a citizen, by supplying the requisites for his moral cultivation, his social security, and his health, it will not be denied that the Medical Profession is no less a matter of national concern and moment than the Church and the Law. ${ }^{43}$

This ensured that the medical profession attained its rightful place at the head of the national learned class in this, the third epoch of history. And of all the duties of the medical profession, Green believed that the one which most justified its pre-eminence was its role as the "guardians of the public health". ${ }^{44}$

Green, then, saw his own pronouncements on medical reform as the means to achieve a Coleridgean State, in which medicine occupied a pre-eminent position in the national learned class. Green, however, was never to be in a position to impose his beliefs on the government of the day. For one thing, his task as Coleridge's literary executor-with its demand that he should systematize Coleridge's philosophy—was an onerous one. His pupil John Simon, however, was to enter central government and exactly how he tried to implement Coleridge's ideas is the subject of the next section. Suffice it to note here that Simon's first publication, written in 1842 when he was twenty-six and unknown outside King's, was a pamphlet on medical education. ${ }^{45}$ Whilst much more limited in scope than Green's extensive writings on the subject, its style and content reveal the latter's influence. ${ }^{46}$

\section{III}

If the publication in 1842 of a pamphlet on medical education by a little-known surgeon of King's went largely unremarked, that of Chadwick's Report on the sanitary condition of the labouring population most certainly did not. One of its many consequences was the Public Health Act of 1848, which established the General Board of Health under Chadwick and his team of sanitary engineers. Simon was not himself to become Medical Officer to the Board until 1855, after Chadwick's fall from grace, but 1848 saw his first foray into the field of public health as Medical Officer of Health for the City of London. Simon presented a series of annual reports relating to the sanitary condition of the City to its Commissioners of Sewers between the years 1849 and 1853 . They were much praised by The Times and made his name. ${ }^{47} \mathrm{His}$ appointment in 1855 as Medical Officer to the Board of Health was quickly followed by W. F. Cowper's succession to its vacant Presidency. Political repercussions from the previous Chadwickian era had rendered the continuance of the Board during the

${ }^{42}$ Green, op. cit., note 23 above, p. 41.

${ }^{43}$ Idem, Suggestions, op. cit., note 38 above, p. 5.

44 Ibid.

${ }^{45}$ Simon, op. cit., note 28 above.

46 E.g., "a single centre of educational government", ibid., p. 23.

47 J. Simon, Reports relating to the sanitary condition of the City of London, London, John W. Parker and son, 1854. 


\section{T. N. Stokes}

period 1854-8, according to Simon, "precarious; and the prospects of further progress in sanitary reform were always extremely uncertain". ${ }^{48}$ But the Board did have as its one legislative success the 1858 Medical Act. The General Board of Health was abolished in 1859 and Simon became Medical Officer to the Privy Council, a post which he held until his retirement in 1876. He thus spent twenty-eight years in public administration, seven in a local capacity as Medical Officer to the City of London, and twenty-one in Central Government. Plenty of time, in fact, for Simon to implement Coleridgean ideas on medical reform.

It was in 1854, the year before Simon entered central government, that his plans for state medicine first appeared, in his preface to the unofficially published Reports relating to the sanitary condition of the City of London. ${ }^{49}$ Here he lamented the fact that Medicine, unlike the Law and the Church, was "dissevered" from the State because the legislature recognized "no Medical Authority". 50 A necessary preliminary to the setting up of this authority was the reform of the medical profession. The unreformed profession was not fit to be a department of the State while it remained in a "state of anarchy and confusion" in which "internal dissension" and the "antagonism, perhaps the jealousies, of rival corporations and of different professional classes" 51 were rife. Once this had been achieved then the "medical authority" could be established. Simon proposed that this should exist as,

some single department of the executive, as the sole charge; that there should be some tangible head, responsible - not only for the enforcement of existing laws, such as they are or may become, but likewise for their progress from time to time to the level of contemporary science, for their completion where fragmentary, for their harmonisation where discordant. ${ }^{52}$

The role of the "medical authority" was, "in the widest sense, to care for the physical necessities of human life",53 to regulate, among other things, public health, vaccination against smallpox, the sale of poisons, food adulteration, and the medical profession. The reader is referred to Lambert's study for an account of how Simon attempted to achieve this end in his capacity as Medical Officer to the Board and subsequently to the Privy Council. But of these regulatory functions Simon believed that public health was the most important and called for the setting up of a sanitary "medical police". 54 For unlike "Curative Medicine", which merely ministered "step by step to the individual units of a population" and thus could "produce only minute and molecular changes in the health of society", "Sanitary Law, embodying the principles of Preventive Medicine" was able to "ensure to the aggregate masses of the community prolongation of life and diminution of suffering". 55 In other words, Simon's desire to reform the medical profession and to give it control over public

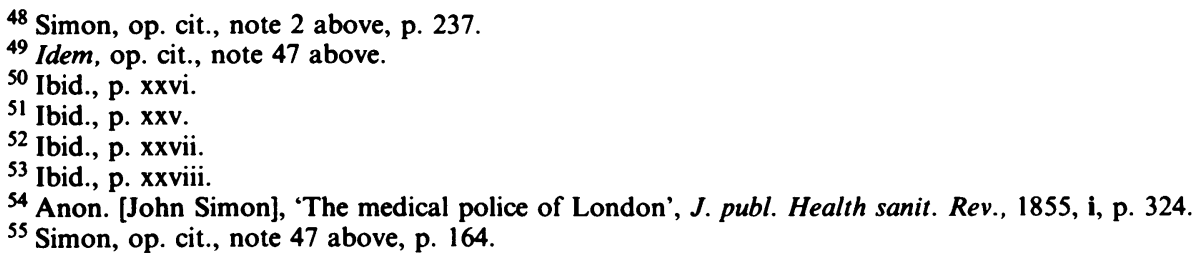


health matters was to make it fit to join the Law and the Church-in Green's and Coleridge's words-in the "clerisy, or national learned class".

Simon's plans for medical reform closely followed those of Green. Thus he proposed that existing discrepancies should be harmonized through one universal and uniform standard of admittance into the profession by way of a primary qualification. This qualification should include both medicine and surgery, and the examinations should be conducted by three conjoint boards representing the old licensing bodies and operating in each division of the United Kingdom. There was also to be a register of legally "qualified medical practitioners", and only those on the register were to "hold any public medical appointment, or to give any medical certificate, or to recover payment for any medical attendance". 56 Simon believed that registration would benefit both the public and the profession, by defining those members fit, in Green's words, to join the national learned class and thus be employed by the State. His most important proposal, however, was for the creation of a General Medical Council which would be both directly accountable to Parliament and have "full regulating powers as to the future conditions of medical qualification". 57 For, as he told readers of The Times in March 1856,

If the large powers asked for are to be given, they must be in harmony with the other institutions of the country; not centralized among the delegates of corporations; or committed to the haphazard results of professional popularity ... but made part of our common Executive.

It is for all interests, medical and public, that so important a branch of Government should not be self-included and irresponsible; that it should depend on some recognized department of State, and thus work under constant liability to Parliamentary question; that its responsible head should be in the great national Council ... where he may be challenged to show that medical legislation is working for the public good. ${ }^{58}$

Simon accepted in principle Green's Coleridgean criteria for admission to the Council. That is to say, he did not want to allow either "universal professional suffrage" to produce an elected Council, or the dominance of delegates of the medical corporations, who would merely voice their particular interests. Simon desired instead that the Council be "intrusted to the very best men in the profession-to men of high education, large minded, deliberative, just, and not only incorruptible but unprejudiced". ${ }^{59}$ He was successful in blocking "universal professional suffrage" but in his 1858 'Memorandum' he acknowledged the political muscle of the corporations and proposed a compromise which was embodied in Cowper's Bill-seventeen members of Council were to be delegated by different universities and medical

\footnotetext{
$56 \mathrm{~J}$. Simon, 'Memorandum prepared in 1858 by the Medical Officer of the General Board of Health', in idem, Public health reports, 2 vols., London, J. \& A. Churchill, 1887, vol. 1, p. 491.

57 Simon, op. cit., note 2 above, p. 273.

58 The Times, 22 March 1856 (letter on medical legislation by "S. T. H.", i.e., a surgeon at St Thomas's-known to be J. Simon).

59 Ibid.
} 


\section{T. N. Stokes}

corporations, and six members were to be appointed by the Crown. Simon hoped that this would ensure that "those particular interests shall not be too partially considered". 60

\section{IV}

Simon's 1858 'Memorandum'-the contents of which were embodied in Cowper's Bill-represented the first of his attempts to install Medicine in its rightful position as one of the chief departments of State ${ }^{61}$ As he was to write forty years later: "The year 1858 deserves a white mark among the years of sanitary progress because in it was passed the Act of Parliament . . . which first gave a statutory constitution to the Medical Profession of the United Kingdom". ${ }^{2}$ Simon had acquired, through Green, a Coleridgean ideology which motivated his considerable labours in public administration. This ideology was every bit as doctrinaire as Chadwick's Benthamism, but was diametrically opposed to it. For Chadwick, according to his biographer S. E. Finer, "propped up, and organized the regime of free competition, profitability, and individualism by the stringent sanctions of Benthamite administration". ${ }^{63}$ Chadwick also believed that it was through sanitary engineering, not medicine, that the health of the greatest number of individuals was to be secured. But not only did Simon champion the cause of medicine in public health, his proposals were in essence anti-individualistic and relied on an organic view of society. On the one hand, his plan for the Medical Council, with its opposition to both "universal professional suffrage" and sectional interests, was in keeping with Coleridge's pronouncement that "there is no unity for a people but in a representation of national interests; a delegation from the passions and wishes of the individuals themselves is a rope of sand". ${ }^{64}$ On the other, he felt that his plans were, like those of Coleridge, based on the natural laws of society. Hence Simon could define Chadwick's debt to Bentham as a "strong theoretical disposition to rely less directly on natural forces in society, and more directly on organised control" ${ }^{65}$ It will thus come as no surprise to learn that Simon and Chadwick's relationship was no more than cordial, ${ }^{66}$ and that Chadwick regarded the years $1854-75$, which saw Simon ushering in the era of state medicine, as "bitterly disappointing" ${ }^{67}$ If one accepts that Simon was a Coleridgean, was his a lone voice or can one speak of a transmission of Coleridgean ideas into Victorian public administration which rivalled those of Bentham? ${ }^{68}$ While an analysis of Simon's own circle at the Board of Health lies outside the scope of this paper, a strong case can be made for the transmission of

${ }^{60}$ Simon, op. cit., note 56 above, i, p. 499.

61 If one ignores for a moment his possible influence on the 1856 Select Committee Report.

62 Simon, op. cit., note 2 above, p. 269.

${ }^{63}$ S. E. Finer, The life and times of Sir Edwin Chadwick, London, Methuen, 1952, p. 26.

64 S. T. Coleridge, Table talk, quoted in A. B. C. Cobban, Edmund Burke and the revolt against the eighteenth century, 2nd ed., London, George Allen \& Unwin, 1960, p. 169.

${ }_{65}$ Simon, op. cit., note 2 above, p. 222.

${ }^{66}$ Lambert, op. cit., note 4 above, pp. 162-3.

${ }^{67}$ Finer, op. cit., note 63 above, p. 501.

68 See idem, 'The transmission of Benthamite ideas 1820-50', in G. Sutherland (ed.), Studies in the growth of nineteenth-century government, London, Routledge and Kegan Paul, 1970, pp. 11-32. 


\section{John Simon and the reform of the medical profession}

Coleridgean ideas in the genesis of the Victorian civil service. 69 "The indispensible category for analysing the Northcote-Trevelyan programme", according to Gowan, "is Coleridgean conservatism, understood as a dynamic, reforming current for shoring up the aristocratic-oligarchic state and social order against the threat from democracy and the working class."70 He argued that many of the key men involved-Benjamin Jowett, W. E. Gladstone, and Robert Lowe-were Coleridgeans, and showed how the Northcote-Trevelyan report's implementation replaced the existing Benthamite training programme with one committed to producing an "intellectual aristocracy"-a new administrative élite of Oxbridgeeducated upper middle-class men. Simon, it would appear, was not the only figure in Victorian public administration with a Coleridgean ideology.

\section{V}

Simon did not prepare his 1858 'Memorandum' for a Parliament ignorant of the medical reform issue. On the contrary, between 1840 and 1858, the year of the Medical Act, sixteen Medical Reform Bills came before Parliament; and at least one Home Secretary, Sir James Graham, was driven to despair in his endeavour to find a solution satisfactory to all the parties concerned. ${ }^{71}$ But there was method in all this Parliamentary manoeuvring. ${ }^{72}$ The campaign for medical reform of the 1840 s was largely a matter of the general practitioners' unsuccessful attempt to democratize the College of Surgeons and, when this proved impossible with the passage of the College's 1843 Charter, to found a College of General Practitioners. ${ }^{73}$ That of the 1850s, however, was primarily concerned with who should have control of the medical profession: should the State gain control of the profession, as Cowper and Simon wanted; or should it continue to rest in the hands of the Royal Colleges? In the latter campaign, which led to the 1858 Medical Act, the general practitionersrepresented by Sir Charles Hastings's Provincial Medical and Surgical Association ${ }^{74}$ (PMSA) - were, once they had provided the initial spur to reform, an irrelevance.

This 1850 s campaign had two phases. In the first (1854-6), ${ }^{75}$ which began with the PMSA's draft Medical Bill of $1854,{ }^{76}$ the Royal Colleges did not act in concert and felt free to pursue their own separate demands concerning medical reform. On the one hand, the College of Physicians was quite prepared to support the general practitioners' call for an outlaw of "quackery" and to allow them parity with the surgeons, so long as physicians kept their position at the top of the hierarchy. This

\footnotetext{
${ }^{69}$ Gowan, op. cit., note 11 above.

70 Ibid., p. 33.

${ }^{71}$ Newman, op. cit., note 2 above, remains the standard work on the history of the Parliamentary medical reform movement. Waddington, op. cit., note 3 above, only deals in detail with the period August 1856 to November 1858.

72 This is discussed at greater length in Stokes, op. cit., note 1 above, chapter 5.

${ }^{73}$ Loudon, op. cit., note 3 above, pp. 282-96; Waddington, op. cit., note 3 above, chapter 5.

74 The PMSA, which became the British Medical Association in 1856, was founded in 1832 by Charles Hastings to unite provincial medical practitioners into "an association friendly and scientific". It opposed medical radicalism and had a membership composed predominantly of provincial physicians and surgeons. See W. H. McMenemy, The life and times of Sir Charles Hastings, Edinburgh, E. \& S. Livingstone, 1959.

75 Stokes, op. cit., note 1 above, pp. 50-54.

${ }^{76}$ Printed in the Lancet, 1854, i: $25-9$.
} 


\section{T. N. Stokes}

dominance was to be maintained by demands that the physician should continue to know no surgery and not be entitled to sue for fees. ${ }^{77}$ On the other, the College of Surgeons-whose position on medical reform was succinctly expressed in Sir James Graham's first Medical Bill of $1844^{78}$ — preferred a single-tier Medical Register (i.e., one which lumped together all three grades of the profession) to a two-tier register which placed the surgeons with the general practitioners yet left the physicians untouched. They also felt strongly that the legislature should not act to outlaw "quackery" per se. ${ }^{79}$ But in the second phase of the campaign (1856-8), the threat of a government-sponsored Bill to take the medical profession out of the hands of the medical corporations, and place it firmly in the hands of the State, stung the Royal Colleges into an alliance to oppose what one official called such "un-English despotism".80

This second phase began with the appearance on the scene in April 1856 of the newly-appointed President of the Board of Health, W. F. Cowper. Cowper took the two private member's Bills on medical reform which were then before the House ${ }^{81}$ and referred them to a Select Committee of which he was the chairman. ${ }^{82}$ The Bill which resulted was, as the College of Surgeons bitterly noted, "in all its main points a new Bill"83 which distinctly bore Cowper's impress. In short, Cowper's Select Committee Bill ${ }^{84}$ proposed the setting up of a Medical Council which was to be a department of State. It was to consist of the President of the Board of Health (i.e., Cowper) and twelve persons nominated by the Crown. Moreover, graduates in medicine were allowed to be registered without their being a member of one of the corporations, and the register was to be alphabetical (single-tier): the physicians, surgeons, and general practitioners were all to be lumped together on a register which allowed its members to call themselves "Licentiates in Medicine and Surgery". One implication of this is that Cowper expected that physicians should know something of

\footnotetext{
77 The position of the governing élite of the College of Physicians towards medical reform is discussed in Stokes, op. cit, note 1 above, chapter 2. It is argued that the College in the 1840s and 50s was living on the legacy of Sir Henry Halford's presidency (1820-44). Under him the College had strengthened its ties with the unreformed administration, the Established Church, and the Bar.

${ }^{78}$ Bills Public (BP), 1844, III, pp. 235-45. Sir Benjamin Brodie (President of the RCS in 1844, and a member of Council 1829-62) was believed by many of his contemporaries to be the man behind Sir James Graham's efforts to reform the medical profession. See J. F. Clarke, Autobiographical recollections of the medical profession, London, J. \& S. Churchill, 1874, pp. 386-7.

79 The position of the governing élite of the College of Surgeons towards medical reform is discussed in Stokes, op. cit., note 1 above, chapter 3. It is argued that, in contrast to the College of Physicians, the dominant faction within the College of Surgeons, which was led by Sir Benjamin Brodie, sought from the late 1820 s to "reform" the medical profession. Brodie was a Whig who wanted to assimilate the new class of general practitioner into the existing corporate structure, seeing the latter as a concession which averted the destruction of the hierarchial nature of the medical profession.

${ }^{80} \mathrm{Dr}$ Wood, President of the Royal College of Surgeons of Edinburgh, see note 110, below.

81 Those of T. E. Headlam, the barrister and Whig MP for Newcastle (BP, 1856, V, pp. 119-37) and Lord Elcho, the Scots peer who had been a junior minister under Aberdeen's Coalition Government of 1852-55 (BP, 1856, V, pp. 157-69).

82 Its members were the following: Cowper, Headlam, Craufurd, Strutt, Howard, Percy (who represented the profession and the public); Heathcoate (who represented the English universities); Napier and Colonel Dunne (who represented Ireland); Black and Hastie (who represented Scotland); Bell (who represented the druggists); and Lord Grosvenor (who represented the "irregulars"): Lancet, 1856, i: 436.

83 Ibid., p. 699.

${ }^{84} B P, 1856, \mathrm{~V}$, pp. $139-55$.
} 


\section{John Simon and the reform of the medical profession}

surgery, and vice versa. Cowper's own politics were hardly sympathetic to the medical corporations, since he was closely allied with Simon and Ruskin. "If Mr. CowperTemple, as a practical politician, could not always follow Ruskin into details", Cook and Wedderburn wrote, "he sympathised fully with his friend's aims". 85 Simon drafted Cowper's Medical Bill of March 1858, but there would appear to be no documentary evidence available to link the Select Committee Bill of 1856 with Simon. ${ }^{86}$ Nonetheless, we may conclude that Cowper, even if he did not consult Simon over the 1856 Bill, both knew and agreed with the opinions expressed in Simon's Reports of $1854 .^{87}$

At this Bill the Royal Colleges took fright, and with good reason. Cowper had been a junior minister in Palmerston's administration and as Palmerston's step-son and a nephew of Lord Melbourne he was exceedingly well connected. There was thus a definite possibility that the government ${ }^{88}$ might take up the Select Committee Bill or else back any subsequent Bill brought in by Cowper in his capacity as President of the Board of Health (which did in fact happen in late 1857). The strength of the Royal Colleges' feeling on the matter can be gauged by the College of Surgeons' reaction to the Select Committee Bill:

The Medical Bill, as reported to the House of Commons by the select committee, would in effect destroy the College by transferring its powers to an untried, uncertain, and fluctuating body, of purely experimental character, called a Medical Council. ${ }^{89}$

The threat of government legislation from this quarter was enough to make both Royal Colleges form an alliance. This alliance bore fruit in late October 1856 with the circulation of the London Corporations' own Medical Reform Bill. ${ }^{90}$ Its key was the phrase that "as far as possible, all existing rights and privileges are to remain untouched". 91 The Royal Colleges' Bill differed from Cowper's Select Committee Bill in three important respects. First, the Crown nominees on the Medical Council were to be a minority. ${ }^{92}$ This meant that the Council first and foremost represented the medical corporations: it could not claim to be the medical department of the State. Secondly, all persons registered had to hold a licence from or be a member of one of the Royal Colleges. Thirdly, the proposed "two-tier" register, one for the physicians and one for the surgeons and general practitioners, ensured that the physician should

\footnotetext{
${ }^{85}$ Ruskin, op. cit., note 16 above, vol. 36, p. xcix. Cowper, who became Cowper-Temple in 1869, held a succession of government posts from 1841 to 1866 . He was perhaps best known for his amendment to Forster's Education Bill of 1870 which became known as the Cowper-Temple clause (DNB).

${ }^{86}$ Simon, it would appear, first acted for Cowper on the subject of medical reform in January 1857, when he wrote a letter on behalf of Cowper to the Registrar of the College of Physicians requesting a copy of the London corporations' own Reform Bill. Waddington, op. cit., note 3 above, p. 100.

${ }^{87}$ Simon, op. cit., note 47 above. Was Cowper a Coleridgean? I do not know. An analysis of Simon's circle at the Board of Health might provide an answer.

${ }^{88}$ Lord Palmerston was PM from February 1855 to February 1858.

89 'Statement issued by the Royal College of Surgeons of England in reply to the 1856 Select Committee Report' signed by William Lawrence (President) and Benjamin Travers and Edward Stanley (VicePresidents). Lancet, 1856, i: 699.

${ }^{90}$ Printed in the Lancet, 1856, ii: 522.

91 Ibid.

92 The Council was to consist of 17 representatives of the medical corporations and the universities, and 6 representatives nominated by the Crown.
} 


\section{T. N. Stokes}

continue to know no surgery and not be entitled to sue for fees. Headlam ${ }^{93}$ agreed to introduce the Corporations' Bill into the Commons, but not before the Royal Colleges had approached Palmerston, informing him that "they proposed introducing a Bill of their own and asked that, in the light of this information, the government refrain from bringing in any Bill until the Bill projected by the corporations had been prepared and considered". 94 Headlam duly introduced this Bill into the Commons on 15 May $1857 .{ }^{95}$ Although no government Bill was forthcoming, Headlam's Bill did not go unopposed. Two days later Lord Elcho ${ }^{96}$ reintroduced into the House the Select Committee Bill of $1856 .{ }^{97}$ This amounted to little more than a paper protest, however, for Headlam's Bill passed its second reading comfortably (on $1 \mathrm{July}$ ) and Elcho withdrew his Bill. ${ }^{98}$ There was, however, little chance that the Colleges' Bill would become law without government support and, despite the Colleges having sent a deputation to both Grey (the Home Secretary) ${ }^{99}$ and Palmerston (the Prime Minister), ${ }^{100}$ that support was not forthcoming. Headlam was thus left with little choice but to inform the Colleges at the end of that session of Parliament that he was dropping the Bill.

The initiative now rested with Cowper at the Board of Health, and on 11 December he announced his intention to introduce a Medical Reform Bill into the Commons in the New Year. This he did on 23 March 1858. Cowper's 1858 Bill, ${ }^{101}$ as I have already argued, represented Simon's first attempt to install Medicine in what he saw as its rightful position as one of the chief departments of State. Waddington has dealt with the actual passage of the Bill in detail, ${ }^{102}$ and only a summary is necessary here. The Royal Colleges were, of course, opposed to the idea of a state Medical Council with extensive regulatory powers. Knowing that another Bill would not get government backing, they used Headlam as their spokesman in the House and approached the Home Secretary directly. They were now in a stronger position than formerly, for Lord Palmerston's Whig administration had fallen in February 1858, and was succeeded by Lord Derby's Conservative ministry in which the new Home Secretary was Spencer Walpole. As a consequence, Cowper had to bring in his Bill as a private member's Bill, and he only secured government co-operation at the expense of giving Walpole a free reign over the Bill's proposals. As Simon later put it: "it was taken out of his [Cowper's] hands, and adopted by Mr. Walpole, and the changes were made under Mr. Walpole's auspices". ${ }^{103}$ Walpole made it perfectly clear at the second reading of the Bill that Cowper must:

${ }^{93}$ See note 81 .

94 Waddington, op. cit., note 3 above, p. 99.

${ }^{95} B P, 1857$, III, pp. 257-75.

${ }^{96}$ See note 81 .

97 BP, 1857, III, pp. 277-93.

${ }^{98}$ He reintroduced it on 16 March 1858, withdrawing it after Cowper's Bill was brought into the House a week later (BP, 1857-8, III, pp. 493-509).

9929 May (reported in the Lancet, 1857, i: 588-9).

1009 June (reported ibid., pp. 612-4).

101 BP, 1857-8, III, pp. 461-75.

102 Waddington, op. cit., note 3 above, chapter 6, pp. 105-32.

${ }^{103}$ Special Report from the Select Committee on Medical Act (1858) Amendment (No. 3) Bill (Lords) (SRSCMA), 1878-9, xii, Q 558. 


\section{John Simon and the reform of the medical profession}

reconsider two points in his Bill: the one was the enormous power given to the Council, which he feared would defeat the independent action of the medical bodies; and the other was that there was no provision for keeping alive the distinct and separate action of these bodies. ${ }^{104}$

This Cowper did. The 1858 Medical Act ${ }^{105}$ differed from his original Bill in a number of important respects. Gone was the clause which established a Medical Council answerable to Parliament with extensive regulatory powers to define both the nature of medical education and the Medical Register. Gone was the clause which demanded that the physician should know something of surgery. A clause was also added which allowed physicians to keep their honorariums, that is, the right not to be able to sue for fees.

It would be wrong, however, to see the changes wrought on Cowper's Bill during its passage through Parliament simply as indications of the disproportionate influence wielded by the Royal Colleges in government affairs. Undoubtedly Walpole lent his ear to the Colleges' requests; but Walpole was a man of robust prejudices, ${ }^{106}$ who most likely implemented their demands because they concurred with his own political ideology (which was held, with minor variations, by the majority of members on either side of the House). This ideology was Whig, with its twin demands of retrenchment and "moderate reform". It found strong support in a mid-Victorian Parliament which "not only thought of itself as the ruling assembly of a highly stable society but was also in strong reaction against any suggestion that it should be otherwise" ${ }^{107}$ We know that this was true for Walpole because he wrote two long articles in the Quarterly Review ${ }^{108}$ in which he stressed the finality of the 1832 Reform Act. As he noted,

the word Reform ... has never meant the demolition of one system and the reconstruction of another ... it meant the continuance of a system which experience and reason had equally approved of, and which only required reparation, expansion, and adaptation, that it might comprehend the old as well as the new requirements of a growing community. ${ }^{109}$

This Whig view of reform was held by the Royal Colleges in the late 1850s. As a member of the Royal Colleges deputation told Palmerston in June 1857:

It should not be forgotten that those institutions [the medical corporations] are peculiarly British; they do not exist abroad; they were established in strict conformity with the principles of the British constitution, and with the view of giving the medical profession the power of self-government. To disturb them, therefore, would be to retrograde, and not to progress in legislation. To hand over the profession to be

104 Hansard, 2 June 1857.

10521 \& 22 Vict., c. 90.

106 As when he retired from office in January 1859 in opposition to Lord Derby's Parliamentary Reform Bill $(D N B)$.

${ }^{107}$ M. Cowling, 1867 Disraeli, Gladstone and revolution, Cambridge University Press, 1967, p. 2.

108 Anonymous but the author known to be Walpole (DNB): Quarterly Review, 1859, 212: 542-62 and 1860, 213: 220-66.

${ }^{109}$ Ibid., 1859, 212: 555. 


\section{T. N. Stokes}

regulated solely by a council appointed exclusively by the Crown, as the Bill of Lord Elcho proposes [that of the 1856 Select Committee], would be to establish an un-English despotism. ${ }^{110}$

Such a Whiggish sentiment would have found much support from Spencer Walpole and other members of the government.

The traditional view of the 1858 Medical Act is that it was a "typical Victorian compromise in attempting to establish something new (the General Council of Medical Education and Registration) without doing too much harm to the old (the 21 corporations in existence with some sort of examining and licensing powers)". ${ }^{11}$ In this compromise, so the story goes, the general practitioners were disappointed in their three principal demands as embodied in Cowper's original Bill, namely, a voice in the government of the existing medical corporations, examination in all three branches (medicine, surgery, and midwifery) of the profession, and a single-tier register which admitted no privileges to the physicians and surgeons. The Royal Colleges were able to exert an influence in government during the Bill's passage out of all proportion to their size in the profession as a whole. ${ }^{112}$ Such a view is, however, misleading to say the least. Undoubtedly the general practitioners had strong views on what provisions should be embodied in the 1858 Medical Act-as the pages of the Lancet and the Provincial Medical and Surgical Journal testify. But there would appear to be little evidence that any of the three protagonists (Simon and Cowper, the College of Physicians, and the College of Surgeons - four, if the Home Secretary is included) felt themselves bound to act by, or even to take notice of, the "medical public opinion" of the general practitioners. ${ }^{113}$ The debates of $1856-8$ were about whether the state or the medical corporations should control the medical profession; the demands of the general practitioner, however laudable they may seem in retrospect, were simply irrelevant to this dispute. Instead, the 1858 Medical Act represented a balance of power between Simon and Cowper, on the one hand, and the two Royal Colleges on the other.

Simon, for his part, sought to impose an "un-English depotism" upon the Royal Colleges and the Government of the day, through Cowper's 1858 Bill with its "demolition of one system (the medical corporations) and the reconstruction of another (State Medicine)". In this he was implementing Coleridgean ideas on medical reform, transmitted to him by his mentor J. H. Green, which sought to make the medical profession a department of State. Not surprisingly he failed; and Simon always regarded the fact that the Medical Council lost its original power to "define the conditions of qualification for admission to the Medical Register" and "compel

${ }^{110}$ Dr Wood, President of the Royal College of Surgeons of Edinburgh. Lancet, 1857, i: 612-14.

111 D. L. Cowen, 'Liberty, laissez-faire and licensure in nineteenth-century Britain', Bull. Hist. Med., 1969, 43: 30-40, p. 32; see also W. L. Burn, The age of equipoise, New York, Norton, 1964, pp. 202-11, and T. R. Gourvish, 'The rise of the professions', in T. R. Gourvish and Alan O'Day (eds.), Later Victorian Britain 1867-1900, London, Macmillan Education, 1988.

112 This is Waddington's conclusion: op. cit., note 3 above, pp. 126-7.

113 Loudon, for one, holds that: "The opportunity for radical changes in the structure of the medical profession was largely confined to the brief period from 1820 to 1850 ". Op. cit., note 3 above, p. 297. 
combinations of examining authorities" as meaning that Cowper's Bill "was mutilated in an essential part". ${ }^{114}$

But Simon's despair stands in stark contrast to the "quiet satisfaction" 115 with the 1858 Medical Act manifested by the Royal College of Surgeons and the Royal College of Physicians, which had both maintained their traditional dominance within the profession. Of the two Royal Colleges, perhaps that of the surgeons was most pleased with the result - given the Act's single-tier alphabetical register and lack of restriction on unlicensed practice per se. These two features cannot have been popular with the College of Physicians. The conclusion that the interests of the surgeons were best served by the Act receives support from the fact that in August 1858 the President of the College of Surgeons "congratulated the Council on the settlement, for the present at least, of the long agitated subject of Medical Reform". ${ }^{116}$ But this is hardly a surprising conclusion, for the ideology of the College of Surgeons was a mirror of the ideology of the ruling political élite which embraced both the Conservatives under Peel and the Whigs under Lord John Russell. ${ }^{117}$ It was, however, inimical to the Coleridgean ideology of Simon. This ideology was Whig; and the 1858 Medical Act can thus be regarded as a typically Whig concession towards the principle of state control of the medical profession, a concession which brought no real transfer of power. The Medical Council was shorn of its extensive regulatory powers during the passage of Cowper's Bill through Parliament. Simon was later to renew his offensive, but that is another story.

114 SRSCMA, Q 554; 553.

115 Waddington's phrase: op. cit., note 3 above, p. 129.

116 Ibid., p. 131.

117 Walpole, op. cit., note 109 above, p. 555. 